\title{
COMPARISON OF EFFECTIVENESS AND SAFETY OF ANTIARRHYTHMIC DRUGS CLASS IC AND III IN PATIENTS AFTER ELECTRICAL CARDIOVERSION
}

\author{
Aldis Strēlnieks ${ }^{1,4, \#}$, Alberts Bērzinš3 ${ }^{3}$, Māra Karakone ${ }^{3}$, Irina Pupkeviča ${ }^{2,4}$, \\ Kristīne Jubele ${ }^{2,4}$, Maija Vikmane ${ }^{2,4}$, Sandis Sakne ${ }^{2}$, Oskars Kalējs ${ }^{2,4}$, \\ Aivars Lejnieks ${ }^{1,4^{3}}$

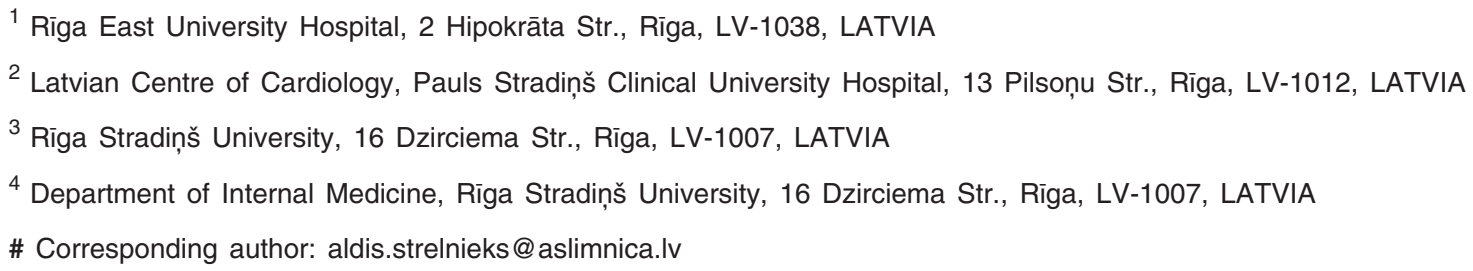

Communicated by Aivars Lejnieks

\begin{abstract}
Patients with atrial fibrillation are faced with an increased risk of thromboembolic events, myocardial infarction, chronic heart failure and death. For some patients with atrial fibrillation, direct current cardioversion (DCCV) is a strategy that can be used to reacquire sinus rhythm. Our aim was to analyse the most commonly used medications after an electrical cardioversion, the reasons for not using them, the effects of pharmacotherapy on recurrence rates, and compare results with data from studies in 2014. The prospective study includes patients with electrocardiographically confirmed atrial fibrillation who underwent direct current cardioversion, hospitalised at Pauls Stradin̄š Clinical University Hospital (Riga, Latvia). The average age was 64.6 years. 50\% of the patients were female. During the six-month study period, $14.3 \%$ patients were using amiodarone, 8.3\% patients were on etacizine, $7.1 \%$ received propafenone, and $57.1 \%$ used beta blockers in monotherapy or in combination. Warfarin was used in $28.0 \%$ patients, direct oral anticoagulants (DOAC's) in $29.9 \%, 21,4 \%$ of patients received aspirin and $16.7 \%$ did not use any antithrombotic therapy. Comparing the recurrence rate in patients using different antiarrhythmic drugs, amiodarone showed a statistically significant superiority compared to etacizine and propafenone $(\mathrm{p}=0.02)$. The obtained data showed that over four years, the use of anticoagulants increased by $11.6 \%$.
\end{abstract}

Key words: direct current cardioversion, atrial fibrillation, oral anticoagulants.

\section{INTRODUCTION}

Atrial fibrillation (AFib) is the most common arrhythmia affecting more than 33 million people worldwide. It is estimated that there are about 5 million new cases each year. AFib incidence and prevalence increases with age. One in four adults over age 65 years has AFib (Chugh et al., 2010; Lloyd et al., 2004). The main problem faced by patients with AFib is an increased risk of thromboembolic events, as there is a five-fold higher risk of stroke in patients with $\mathrm{AFib}$, as well as an increased risk of myocardial infarction, chronic heart failure and death (Wolf et al., 1991; Go et al.,
2014). Vascular dementia is found in $10-15 \%$ of patients with AFib, which is two times more common than in the population. All of these problems can be detrimental to the quality of life (Ott et al., 1997).

The direct costs of AFib have reached about $1 \%$ of total health expenses in the United Kingdom. Costs in the US amounted to USD 6-26 billion in 2008 (Stewart et al., 2014).

The electrical cardioversion (ECV) technique relies on the application of a selected amount of energy, which is gener- 
ally between 50-360 J, via two electrodes (paddles). A transthoracic direct current shock of sufficient magnitude depolarises the entire myocardium, rendering the entire heart momentarily refractory to repeat depolarisation. Thereafter, the most rapid intrinsic pacemaker, usually the sinoatrial node, reassumes control of heart rhythm (Sucu et al,. 2009).

Direct current cardioversion (DCCV) can be considered as an urgent and optional method for restoring sinus rhythm in patients with AFib (Kirchhof et al., 2007).

Anticoagulants are considered mandatory before scheduled cardioversion in atrial fibrillation, if it lasts more than 48 hours or if the duration of the episode is not known. Because of the increased risk of cardiovascular thromboembolic events, the European Society of Cardiology 2016 guidelines recommend using anticoagulants at least three weeks before and four weeks after the procedure (ECV) (Weinberg et al., 1989; Nuotio et al., 2014; Kirchhof et al., 2016). Patients without therapeutic anticoagulation have a post-procedural thromboembolic risk of 5-7\% (Arnold et al., 1992).

Depending on the source, the frequency of recurrence of AFib after an electrical cardioversion ranges from 40-60\%. Adequate antiarrhythmic therapy does not always affect the frequency of recurrence. There are several risk factors that can influence the frequency of recurrences after ECV, such as age, AFib duration, left ventricular size, etc. (Cannon et al., 2008).

Our goal was to analyse the risk factors of developing recurrence of atrial fibrillation. We assessed the most commonly used medications after an electrical cardioversion and the reasons for not using them as well as the effects of pharmacotherapy on recurrence rate. Finally our aim was to compare the acquired results with data from studies in 2014.

\section{METHODS}

The prospective study was conducted between January and August 2017 at the Latvian Centre of Cardiology, Pauls Stradiňš Clinical University Hospital. The study included 168 patients undergoing scheduled or emergency electrical cardioversion. Patients were hospitalised due to electrocardiographically detected atrial fibrillation either by general practitioner or emergency service. Electrocardiograms were re-acquired at the department where the patient was hospitalised. An authorisation of the Ethics Committee of Rìga Stradiňš University was received. Before the questionnaire, all patients received informative material with a description of the research (in Latvian and Russian). Acquainting with it, all patients provided written consent. An anonymous patient questionnaire was used. Contact information of patients and their relatives as well as demographic data (age, gender) were acquired. Information about the type of admittance at the treatment facility, previous history and duration of AFib, history of AFib associated medication use and previous electrical cardioversion was collected. Medical records provided information about the outcome of electrical cardioversion, history of disease and biochemical parameters from blood tests. Based on the collected data, CHA2DS2-VASc was calculated.

The second questionnaire was developed as a telephone survey for patient control after three and six months. The following questions were asked during telephone interviews: if there has been repeated hospitalisation and the cause for it, recurrence of AFib paroxysms (how many times, type of treatment), drugs used for rhythm control and anticoagulation, an adverse drug reactions. In the case of death, detailed information was gathered from relatives about the cause and treatment previously used by the patient.

The study included patients, aged 31 to 84 years. The average age was 64.6 years $( \pm 10.5)$. Among the 168 patients interviewed, $50.0 \%$ were female. $18(10.6 \%)$ patients were admitted to the hospital by emergency service, while 140 $(83.4 \%)$ patients were referred by a general practitioner or a cardiologist. In $10(6.0 \%)$ cases patients admitted themselves. The duration of AFib paroxysism was less than 24 hours in $2(1.2 \%)$ cases, 24 to 48 hours in $8(4.8 \%), 48$ hours to seven days in $12(7.1 \%)$ and more than seven days in $74(44.0 \%)$ cases. Seventy-two $(42.9 \%)$ patients could not report when the paroxysm had started. One hundred and twelve $(66.7 \%)$ had a history of previous AFib.

Previously, medical cardioversion had been used in 126 (75.0\%) patients and ECV was performed in 66 (39.3\%) patients. Patient baseline characteristics are summarised in Table 1 .

CHA2DS2-VASc was calculated: $12(7.1 \%)$ patients had 0 points, $27(16.1 \%)$ had 1 point and $129(76.8 \%)$ had 2 or more points. The average score was 2.75 . The results of patient thromboembolic risk assessment with the CHA2DS2VASc scale are summarised in Table 2.

Table 1

PATIENT BASELINE CHARACTERISTICS

\begin{tabular}{ll}
\hline & \multicolumn{1}{c}{ Total, $\mathrm{n}(\%)$} \\
\hline Age (mean $\pm \mathrm{SD})$ & $64.6 \pm 10.5$ \\
Age $>65$ years & $98(58.3 \%)$ \\
Gender, males & $84(50.0 \%)$ \\
Body mass index kg/m ${ }^{2}($ mean $\pm \mathrm{SD})$ & $31.7 \pm 5.8$ \\
Arterial hypertension & $104(61.9 \%)$ \\
Chronic heart failure & $44(26.6 \%)$ \\
Diabetes & $32(19.0 \%)$ \\
Myocardial infarction & $14(8.3 \%)$ \\
Stroke & $24(14.6 \%)$ \\
Implanted pacemaker & $8(4.8 \%)$ \\
Radiofrequency catheter ablation & $12(7.1 \%)$ \\
Duration of paroxysm & \\
$\quad<48$ h & $10(5.9 \%)$ \\
$\quad>48$ h & $86(51.2 \%)$ \\
$\quad$ Unknown duration & $72(42.9 \%)$ \\
Electrocardioversion in anamnesis & $66(39.3 \%)$
\end{tabular}


Table 2

PATIENT THROMBOEMBOLIC RISK ASSESSMENT WITH CHA2DS2-VASC SCALE

\begin{tabular}{ll}
\hline \multicolumn{1}{c|}{ CHA2DS2-VASc } & \multicolumn{1}{c}{ Total, $\mathrm{n}(\%)$} \\
\hline 0 & $12(7.1 \%)$ \\
1 & $27(16.1 \%)$ \\
2 & $31(18.4 \%)$ \\
3 & $49(29.2 \%)$ \\
4 & $26(15.5 \%)$ \\
5 & $17(10.1 \%)$ \\
6 & $6(3.6 \%)$
\end{tabular}

Data were entered and processed using Microsoft Excel and IBM SPSS Statistics 22.0. Descriptive statistical methods were used to characterise patient parameters - summary tables with columns, lane graphs or histograms, mean arithmetic and standard deviation. Statistical analysis of qualitative data using the chi-squared $(\chi 2)$ test and Fisher exact test (if the number of expected cases were $\mathrm{n}<5$ in one of the columns in the table). A $p$-value less than 0.05 was considered to determine statistical significance.

\section{RESULTS}

Prior to ECV, amiodarone was used in $80(47.6 \%)$ patients. IC group antiarrhythmic drugs were used in $24(14.2 \%)$, and sotalol was used in $6(3.5 \%)$, Beta blockers (BB) were used in $122(72.6 \%)$, while $78(46.4 \%)$ patients used angiotensin converting enzyme inhibitors (ACEI) inhibitors or angiotensin receptor blockers (ARB). The choice of oral anticoagulants before direct current cardioversion (DCCV) was: warfarin in $44(26.2 \%)$ patients, Xarelto (rivaroxaban) in 64 $(38.1 \%)$ and Pradaxa (dabigatran) in $42(25.0 \%)$. Two (2.4\%) patients were using aspirin, while $6(3.6 \%)$ patients were on dual therapy (combination of an anticoagulant and aspirin).

After six months, three patients had died. The cause of death in all three patients was stroke. One patient did not use anticoagulants, but two of three patients used rivaroxaban and warfarin.

Sixty-two (36.9\%) patients had one repeated episode of AFib and $20(11.9 \%)$ had a repeated episode two or more times. A total of $82(48.8 \%)$ patients had at least one episode of AFib over a period of six months. Fourty-eight (28.6\%) patients were hospitalised due to arrhythmia, six (3.6\%) due to pacemaker implantation, two (1.2\%) due to scheduled radiofrequency ablation (RFCA), four (2.4\%) due to coronary artery bypass grafting (CABG), two (1.2\%) due to primary coronary intervention (PCI) and two patients was hospitalised due to acute decompensated heart failure. Reasons for hospitalisation six months after electrocardioversion are summarised in Figure 1. In 38 (22.6\%) patients arrhythmia was discontinued by ECV, eight $(4.8 \%)$ were treated with medications and in $36(21.4 \%)$ the arrhythmia was not treated at all.

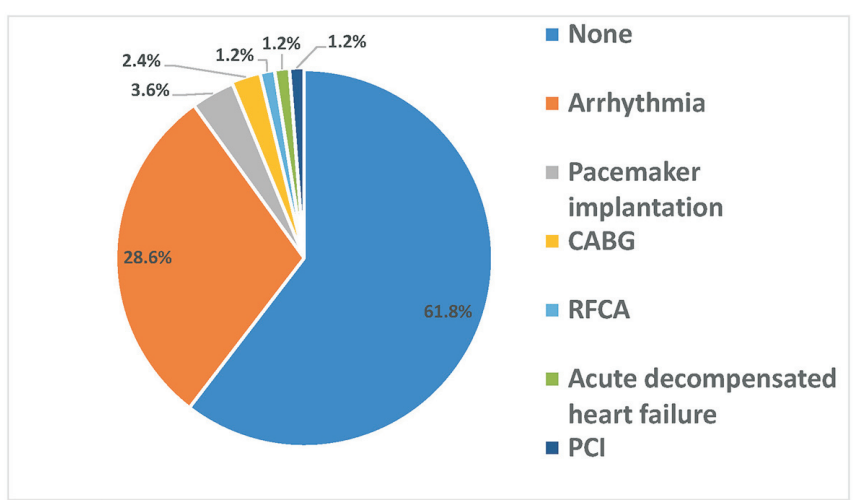

Fig. 1. Reasons for hospitalisation six months after electrocardioversion. CABG, coronary artery bypass grafting; RFCA, radiofrequency ablation; PCI, primary coronary intervention.

During the three-month control, $32(19.3 \%)$ patients used amiodarone, $28(16.6 \%)$ used IC group antiarrhythmic drugs, four $(2.3 \%)$ patients used sotolol, while $122(72.4 \%)$ patients reported using BB. 72 (42.7\%) and $26(15.4 \%)$ patients used ACEI and ARB, respectively. Warfarin was used in $48(28.4 \%)$ patients, Xarelto (rivaroxaban) in $46(27.4 \%)$, Pradaxa (dabigatran) in 14 (8.3\%). Twenty-four (14.2\%) patients were using aspirin, six patients were on a combination of Xarelto and aspirin, while $26(15.7 \%)$ patients did not take any oral anticoagulants.

Later, during the six-month control, 24 (14.3\%) patients were using amiodarone, 14 (8.3\%) patients were on etacizine, $12(7.1 \%)$ received Ritmonorm (propafenone), and 96 (57.1\%) used BB. Sixty (35.7\%) patients used ACEI, while $26(15.4 \%)$ patients were using ARB. Warfarin was used in $47(27.9 \%)$ patients, Xarelto (rivaroxaban) in $34(20.4 \%)$, Pradaxa (dabigatran) in 16 (9.5\%). Thirty-six (21.4\%) patients were taking aspirin, two patients were using a combination of Xarelto and aspirin, while $28(16.7 \%)$ patients did not use any oral anticoagulants.

Of those patients who did not use oral anticoagulants (OAC) after six months, 24 (85.7\%) had CHADS-VASc of two or more. $77.1 \%$ of those using aspirin also had CHADS-VASc of two or more. A total of $29.6 \%$ were not using OAC despite indications.

Observed adverse reactions after six months were: six (3.6\%) patients reported nausea, four $(2.4 \%)$ had minor bleeding, six (3.6\%) patients had cough and six (3.6\%) patients reported having had oedema.

Without statistical significance, recurrence of AFib was more frequent in women vs men ( $60 \%$ vs $43 \%$ ), in patients with diabetes vs without diabetes (56\% vs $49 \%$ ), congestive heart failure vs patients without congestive heart failure (60\% vs $47 \%$ ) and smokers vs non smokers (75\% vs $49 \%$ ). Patients with a history of AFib were more likely to be hospitalised $(47 \%$ vs $21 \%)(p=0.002)$ and have a recurrence $(67 \%$ vs $22 \%)(p<0.001)$. Comparing the recurrence rate in patients using different antiarrhythmic drugs, amiodarone showed a statistically significant superiority compared to etacizine and propafenone ( $41.7 \%$ vs $71.4 \%$ vs $83.3 \%)$ ( $p=$ 


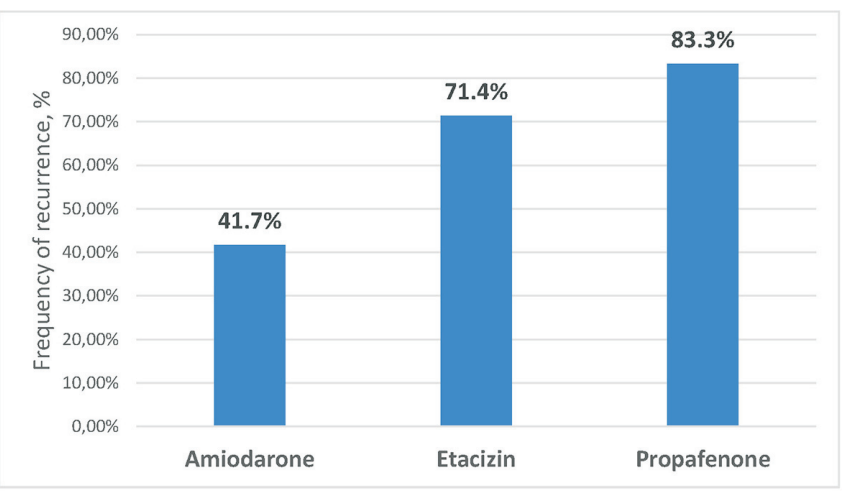

Fig. 2. Comparison of the relapse rate in patients using different antiarrhythmic drugs. Amiodarone showed a statistically significant superiority compared to etacizine and propafenone $(41.7 \%$ vs $71.4 \%$ vs $83.3 \%$ ) $(p=0.02)$

0.02) (Fig. 2). However, in this study we did not include patients who were enrolled in another study comparing a combination of etacizine and beta-blockers to amiodarone.

\section{DISCUSSION}

The incidence of cardiovascular risk factors in the study population was consistent with world literature (Pisters et al., 2012; Femia et al., 2017).

Most of the patients $(83.3 \%)$ in the study population were admitted for a scheduled ECV. $42 \%$ of patients could not report the time of onset of AFib paroxysms as they were asymptomatic. Literature data (Xiong et al., 2015) show that around $40 \%$ of patients with AFib are asymptmatic, which conforms with the data obtained by our study. Patients had found out about their condition while undergoing routine check-ups. The frequency of recurrence of atrial fibrillation in patients after six months corresponds to world literature (Femia et al., 2017). After six months, 64 (38.0\%) patients had been hospitalised, and for 48 (28.6\%) patients the cause of hospitalisation was arrhythmia. The rest of patients were hospitalised mainly due to scheduled procedures.

After a six-month follow-up, three patients had died of stroke, of whom two were on oral anticoagulants (warfarin and rivaroxaban). Both patients had a high risk of thromboembolic events (CHA2DS2-VASc $\geq 2)$. The guidelines of the European Society of Cardiology determine that the optimal INR for patients with non-valvular AFib is 2.0-3.0. According to world literature, roughly $40 \%$ of patients reach the optimal INR succesfully. Achieving the goal can be complicated by drug interactions and diet mistakes (Kirchhof et al., 2016). This might have affected the INR of the patients receiving oral anticoagulation hence resulting in an INR below the therapeutic standard. The bioavailability of Xarelto (rivaroxaban) $15 \mathrm{mg}$ and $20 \mathrm{mg}$ is significantly reduced by $44 \%$ when taken on an empty stomach. (Stampfuss et al., 2013; Heidbuchel et al., 2017). Our study found that approximately $30 \%$ of patients were taking Xarelto on an empty stomach, which increases the risk of thromboembolic events.
Three months after ECV, $64.1 \%$ of patients received anticoagulant therapy $(28.4 \%$ used warfarin and $35.7 \%$ used DOACs), while $14.2 \%$ of patients received aspirin and $15.7 \%$ did not use any antithrombotic therapy. Six months after ECV, anticoagulant therapy was continued by $57.9 \%$ of patients (28.0\% used warfarin and $29.9 \%$ used DOACs), $21.4 \%$ of patients received aspirin and $16.7 \%$ did not use any antithrombotic therapy. When comparing the use of anticoagulants three and six months after ECV, use of anticoagulants had decreased by $6.2 \%$, while the use of aspirin increased by $7.2 \%$. The European Society of Cardiology 2016 guidelines state that aspirin is not indicated in patients with AFib (Kirchhof et al., 2016). There are several reasons for the increse in use of aspirin over time. One is the misinformation of general practitioners, which leads to prescribing aspirin as an alternative for patients who are not financially able to buy DOACs or have difficulties controlling INR. The second reason is lack of general knowledge among patients about their condition, which leads to being easily influenced by misleading information about use of aspirin as an alternative and adequate treatment.

Previous studies (Pupkevica et al., 2014) showed that the use of anticoagulants after six months increased by $11.6 \%$, respectively. DOACs was the biggest contributor to the rise in anticoagulant use. The use of DOACs versus warfarin increased from $1: 3(11.2 \%$ vs $35.1 \%)$ to $1: 1$ (29.9\% vs $28.0 \%)$. Change in the use of antithrombotic therapy six months after electrocardioversion over a period of four years are summarised in Figure 3. This ratio of DOACs and warfarin complies with data from other studies (Olesen $e t$ al., 2015). The use of aspirin after ECV decreased by $15.7 \%$ over six months, respectively. When comparing data over a period of time, the use of aspirin decreases, but remains high. This leads to additional concerns, because $77.1 \%$ of patients taking aspirin had a CHA2DS2-VASc $>2$ and were not protected from thromboembolism.

Previous studies (Strelnieks et al., 2014) showed that the use of amiodarone has decreased by $7.5 \%$, while the use of etacizine has increased by $4.3 \%$. The use of propafenone has remained approximately the same. The use of BB has

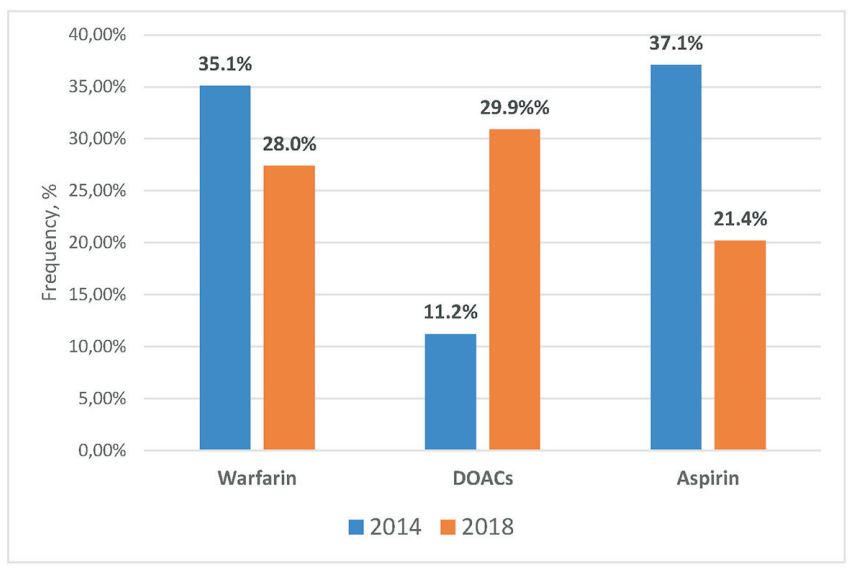

Fig. 3. Change in use of antithrombotic therapy six months after electrocardioversion over a period of four years (2014-2018). DOACs, direct oral anticoagulants. 
decreased by $24.8 \%$. The fall in use of amioadore and BB can be explained by several reasons. In the case of amiodarone, it can be explained by fear of adverse reactions that may be expressed after a prolonged use of the medicament. In the case of $\mathrm{BB}$, another contributor is the vastly available negative information regarding this group of drugs coming from different sources as well as not seeking proper information instead.

Analysing the efficacy of antiarrhythmic drugs, the most effective medication still remains amiodarone, which showed a statistically significant superiority over etacizine and propafenone $(41.7 \%$ vs $71.4 \%$ vs $81.3 \%)(p=0.02)$. The data has limitations, because in our study we did not analyse patients enrolled in another study comparing a combination of etacizine and beta-blockers to amiodarone, in which the combination showed a superiosity to amiodarone.

Examining the risk factors contributing to recurrence, with statistical significance the recurrence presented more often in patients with previously known AFib. Without statistical significance, the recurrence was more often in patients suffering from diabetes and congestive heart disease as well as in smokers, which corresponds to previous data (Strēlnieks et al., 2014). This can be explained by the induced atrial remodelation in patients with these conditions, as structural changes in myocardium lead to local heterogenity of electrical conduction, which can lead to re-entry mechanism and arhythmia.

Observed adverse reactions after six months were: six (3.6\%) patients reported nausea, four $(2.4 \%)$ had minor bleeding, six (3.6\%) had cough and six $(3.6 \%)$ had oedema. The frequency of bleeding caused by antithrombotic agents in our study was found to be lower than reflected in world literature (Camm et al., 2014; Femia et al., 2017). Only $2.4 \%$ of patients complained about minor bleeding and none of the patients experienced serious, life-threatening bleeding.

\section{CONCLUSIONS}

The most commonly used and most effective medication was amiodarone. When comparing the data of patients over four years, the use of anticoagulants increased by $11.6 \%$ and the use of DOACs increased by $18.7 \%$. Although $77.1 \%$ of patients taking aspirin had a CHADS-VASc $\geq 2$, there was still a group of patients taking aspirin instead of anticoagulants, which does not lower the risk of developing thrombembolism. The main reasons for non-compliance were fear of adverse drug reactions, high drug costs as well as negative information regarding the drugs coming from unauthorised sources. With statistical significance recurrence was higher in patients with previously known AFib. $30 \%$ patients of the study population did not know that Xarelto must be taken on an empty stomach, which could lead to thrombembolic events. The number of asymptomatic AFib patients was consistent with global data.

\section{REFERENCES}

Arnold, A. Z., Mick, M. J., Mazurek, R. P., Loop, F. D., Trohman, R. G (1992). Role of prophylactic anticoagulation for direct current cardioversion in patients with atrial fibrillation or atrial flutter. J. Amer. Coll. Cardiol., 19, 851-855.

Camm, A. J., Savelieva, I. (2014) Practical considerations for using novel oral anticoagulants in patients with atrial fibrillation. Clin. Cardiol., 37 (1), $32-47$.

Cannon, C. P., Armani, A. M. (2008). Atrial Fibrillation - From Bench to Bedside. Humana Press. 46 pp.

Chugh, S. S., Havmoeller, R., Narayanan, K., Singh, D., Rienstra, M. Benjamin, E. J., Gillum, R. F., Kim, Y. H., McAnulty, J. H. Jr., Zheng, Z. J., Forouzanfar, M. H., Naghavi, M., Mensah, G. A., Ezzati, M., Murray, C. J. (2014). Worldwide epidemiology of atrial fibrillation: A Global Burden of Disease 2010 Study. Circulation, 129, 837-847.

Femia, G., Fetahovic, T., Shetty, P., Lee, A. (2017). Novel oral anticoagulants in direct current cardioversion for atrial fibrillation. Heart Lung Circ., 27 (7), 798-803.

Go, A. S., Mozaffarian, D., Roger, V. L., Benjamin, E. J, Berry, J. D., Blaha, M. J., Dai, S., Ford, E. S., Fox, C. S., Franco, S., Fullerton, H. J., Gillespie, C., Hailpern, S. M., Heit, J. A., Howard, V. J., Huffman, M. D., Judd, S. E., Kissela, B. M., Kittner, S. J., Lackland, D. T., Lichtman, J. H., Lisabeth, L. D., Mackey, R. H., Magid, D. J., Marcus, G. M., Marelli, A., Matchar, D. B., McGuire, D. K., Mohler, E. R. 3rd., Moy, C. S., Mussolino, M E., Neumar, R. W., Nichol, G., Pandey, D. K., Paynter, N. P., Reeves, M. J., Sorlie, P. D., Stein, J., Towfighi, A., Turan, T. N., Virani, S. S., Wong, N. D., Woo, D., Turner, M. B. (2014). American Heart Association Statistics Committee and Stroke Statistics Subcommittee. Circulation, 129, e28-e292.

Hart, R. G., Pearce, L. A., Aguilar, M. I. (2007). Meta-analysis: Antithrombotic therapy to prevent stroke in patients who have nonvalvular atrial fibrillation. Ann. Intern. Med., 146, 857-867.

Heidbuchel, H., Verhamme, P., Alings, M., Antz, M., Diener, H. C., Hacke, W., Oldgren, J., Sinnaeve, P., Camm, A. J., Kirchhof, P. (2017). Updated European Heart Rhythm Association Practical Guide on the use of non-vitamin $\mathrm{K}$ antagonist anticoagulants in patients with non-valvular atrial fibrillation. Eur. Heart J., 38 (27), 2137-2149.

Kirchhof, P., Benussi, S., Kotecha, D., Ahlsson, A., Atar, D., Casadei, B., Castellá, M., Diener, H. C., Heidbuchel, H., Hendriks, J., Hindricks, G., Manolis, A. S., Oldgren, J., Alexandru, P. B., Schotten, U., Van P. B., Vardas, P. (2016). 2016 ESC Guidelines for the management of atrial fibrillation developed in collaboration with EACTS. The Task Force for the management of atrial fibrillation of the European Society of Cardiology (ESC). Eur. Heart J., 37, 2893-2962.

Kirchhof, P., Monnig, G., Wasmer, K., Heinecke, A., Breithardt, G. Eckardt, L., Bocker, D. (2005) A trial of self-adhesive patch electrodes and hand-held paddle electrodes for external cardioversion of atrial fibrillation (MOBIPAPA). Eur. Heart J., 26, 1292-1297.

Lloyd-Jones, D. M.,Wang, T. J., Leip, E. P., Larson, M. G., Levy, D., Vasan, R. S., D’Agostino, R. B., Massaro, J. M., Beiser, A., Wolf, P. A., Benjamin, E. J. (2004). Lifetime risk for development of atrial fibrillation: The Framingham Heart Study. Circulation, 110, 1042-1046.

Nuotio, I., Hartikainen, J. E., Grönberg, T., Biancari, F., Airaksinen, K. E (2014). Time to cardioversion for acute atrial fibrillation and thromboembolic complications. JAMA, 312, 647-649.

Olesen, J. B., Sørensen, R., Hansen, M. L., Lamberts, M., Weeke, P., Mikkelsen, A. P., Køber, L., Gislason, G. H., Torp-Pedersen, C., Fosbøl, E. L. (2015). Non-vitamin K antagonist oral anticoagulation agents in anticoagulant naive atrial fibrillation patients: Danish nationwide descriptive data 2011-2013. Europace, 17 (2), 187-193.

Ott, A., Breteler, M. M., de Bruyne, M. C., van Harskamp, F., Grobbee, D. E., Hofman, A. (1997). Atrial fibrillation and dementia in a population-based study. The Rotterdam Study. Stroke, 28, 316-321. 
Pisters, R., Nieuwlaat, R., Prins, M. H., Le Heuzey, J. Y., Aldo, P., Maggioni, A., Camm, A. J., Crijns, H. J. (2012). Clinical correlates of immediate success and outcome at 1-year follow-up of real-world cardioversion of atrial fibrillation: The Euro Heart Survey. Europace, 5 (14), 666-674.

Pupkevica, I., Litunenko, O., Vīnkalna, I., Strēlnieks, A., Šime, I., Stirna, V., Kovaḷova, M., Rancāne, R., Miglāne, E., Tilgale, B., Trušinskis, K., Kalējs, O., Lejnieks, A. (2014). Risk of cardiovascular events in patients with atrial fibrillation after electrical cardioversion. RSU Scientific Articles, 4, $122-137$

Singh, S. N., Tang, X. C., Reda, D., Singh, B. N. (2009). Systematic electrocardioversion for atrial fibrillation and role of antiarrhythmic drugs: A substudy of the SAFE-T trial. Heart Rhythm, 6 (2), 152-155.

Stampfuss, J., Kubitza, D., Becka, M., Mueck, W. (2013). The effect of food on the absorption and pharmacokinetics of rivaroxaban. Int. J. Clin. Pharmacol. Ther., 51 (7), 549-561.

Received 11 June 2018

Accepted in the final form 25 November 2018
Stewart, S., Murphy, N., Walker, A., McGuire, A., McMurray, J. J. V. (2004). Cost of an emerging epidemic: An economic analysis of atrial fibrillation in the UK. Heart, 90, 286-292

Strēlnieks, A., Vīnkalna, I., Lituņenko, O., Pupkevica, I., Šime, I., Vikmane, M., Kovaḷova, M., Rancāne, M., Dormidontova, G., Sakne, S., Pudulis, J., Mintāle, I., Kalējs, O., Lejnieks, A. (2014). Atrial fibrillation and risk factors of recurrent paroxysms after electrical cardioversion. RSU Scientific Articles, 4, 137-157.

Sucu, M., Davutoglu, V., Ozer, O. (2009). Electrical cardioversion. Annu. Saudi Med., 29 (3), 201-206.

Weinberg, D. M., Mancini, J. (1989). Anticoagulation for cardioversion of atrial fibrillation. Amer. J. Cardiol., 63, 745-746.

Wolf, P. A., Abbott, R. D., Kannel, W. B. (1991). Atrial fibrillation as an independent risk factor for stroke: The Framingham Study. Stroke, 22, 983-988.

Xiong, Q., Proietti, M., Senoo, K., Lip, G. Y. (2015). Asymptomatic versus symptomatic atrial fibrillation: A systematicreview of age/gender differences and cardiovascular outcomes. Int. J. Cardiol., 191, 172-177.

\section{IC UN III KLASES ANTIARITMISKO MEDIKAMENTU EFEKTIVITĀTES UN DROŠĪBAS SALĪDZINĀJUMS PACIENTIEM PĒC ELEKTRISKĀS KARDIOVERSIJAS}

Ātriju fibrilācija (ĀF) ir visbiežāk sastopamā aritmija, kas skar vairāk nekā 33 miljonus iedzīvotāju. Galvenā problēma, ar ko saskaras pacienti ar $\overline{\mathrm{A}} \mathrm{F}$, ir paaugstināts trombemboliju risks, jo pacientiem ar $\overline{\mathrm{A}} \mathrm{F}$ ir piecas reizes lielāks insulta risks, kā arī paaugstināts miokarda infarkta, hroniskas sirds mazspējas un nāves risks. Prospektīvā pētījumā tika iekḷauti pacienti, kuriem tika veikta plānveida vai akūta elektriskā kardioversija. Pētījumā kopā piedalījās 168 pacienti. Vidējais vecums bija 64.6 gadi. Sešu mēnešu kontroles laikā 14,3\% lietoja amiodaronu, 8,3\% etacizīnu, 7,1\%, propafenonu, $57,1 \%$ beta blokatorus. Kopumā varfarīnu lietoja $28,0 \%$ pacienti, tiešos orālos antikoagulantus lietoja 29,9\%, 21,4\% lietoja aspirīnu, un 16,7\% nelietoja antikoagulantus. Salīdzinot recidīvu biežumu, pacientiem lietojot dažādus AAL, statistiski ticamu pārākumu ieguva amiodarons, salīdzinot ar etacizīnu un propafenonu $(41,7 \%$ pret $71,4 \%$ pret 81,3\%) $(p=$ $0,02)$. 